\title{
Screening for Free Radical Scavenging and Cell Aggregation Inhibitory Activities by Secondary Metabolites from Turkish Verbascum species
}

\author{
I. Irem Tatli ${ }^{\mathrm{a}, *}$, Satoshi Takamatsu ${ }^{\mathrm{b}}$, Ikhlas A. Khan ${ }^{\mathrm{b}}$, and Zeliha S. Akdemir ${ }^{\mathrm{c}}$ \\ a Department of Pharmaceutical Botany, Faculty of Pharmacy, Hacettepe University, Sihhiye, \\ 06100, Ankara, Turkey. Fax: +90-312-3114777. E-mail: itatli@hacettepe.edu.tr \\ b National Center for Natural Products Research, Research Institute of Pharmaceutical \\ Sciences, School of Pharmacy, The University of Mississippi, University, 38677, MS, USA \\ c Department of Pharmacognosy, Faculty of Pharmacy, Hacettepe University, Sihhiye, \\ 06100, Ankara, Turkey \\ * Author for correspondence and reprint requests \\ Z. Naturforsch. 62c, 673-678 (2007); received March 16/April 27, 2007
}

Free radical scavenging and cell aggregation inhibitory activities of 36 secondary metabolites isolated from the methanolic extracts of Verbascum cilicicum Boiss., V. lasianthum Boiss. ex Bentham, V. pterocalycinum var. mutense Hub.-Mor., and V. salviifolium Boiss. (Scrophulariaceae) were investigated. The isolated compounds, 6- $O$-vaniloyl ajugol (1), ilwensisaponin A (2), ilwensisaponin C (3), verbascoside (4), $\beta$-hydroxyacteoside (5), martynoside (6), poliumoside (7), forsythoside B (8), angoroside A (9), dehydrodiconiferyl alcohol-9- $O$ - $\beta$-D-glucopyranoside (10), dehydrodiconiferyl alcohol-9'-O- $\beta$-D-glucopyranoside (11), apigenin 7- $O-\beta$ glucopyranoside (12), luteolin 7-O- $\beta$-glucopyranoside (13), luteolin $3^{\prime}$ - $O-\beta$-glucopyranoside (14) and chrysoeriol 7-O- $\beta$-glucopyranoside (15), exhibited a dose-dependent inhibition of bioautographic and spectrophotometric DPPH activities. Verbascoside (4) was the most active $\left(\mathrm{IC}_{50} 4.0 \mu \mathrm{g} / \mathrm{ml}\right)$ comparing it to vitamin $\mathrm{C}\left(\mathrm{IC}_{50} 4.4 \mu \mathrm{g} / \mathrm{ml}\right)$ to inhibit phorbol 12-myristate 13-acetate (PMA)-induced peroxide-catalyzed oxidation of $2^{\prime}, 7^{\prime}$-dichlorofluorescein (DCFH) by reactive oxygen species (ROS) within human promyelocytic HL-60 cells. Ilwensisaponin A (2) (MIC $6.9 \mu \mathrm{g} / \mathrm{ml})$ showed moderate in vitro activity on lymphocyte-associated antigen-1 (LFA-1)/intercellular adhesion molecule-1 (ICAM-1)-mediated aggregation using the HL-60 cell line [positive control was cytochalasin B (MIC $2.3 \mu \mathrm{g} / \mathrm{ml}$ )]. None of the other compounds showed free radical scavenging and cell aggregation inhibitory activities.

Key words: Verbascum sp., Free Radical Scavenging Activity, Cell Aggregation Inhibitory Activity

\section{Introduction}

Verbascum species (Scrophulariaceae), commonly known as "mullein", are reported to have expectorant, mucolytic and demulcent properties and are used to treat respiratory problems such as bronchitis, dry coughs, tuberculosis and asthma in traditional Turkish medicine. The species are also used to treat haemorrhoids, rheumatic pain, superficial fungal infections, wounds and diarrhoea, and have inhibitory activities against the murine lymphocytic leukaemia and influenza viruses A2 and B (Baytop, 1999; Turker and Camper, 2002).

Our previous studies have resulted in the isolation of 1 monoterpene and 21 iridoid glycosides, 2 oleanane-type triterpenoid saponins, 6 phenylethanoid, 2 neolignan and 4 flavonoid glycosides from V. cilicicum Boiss. (Tatli et al., 2003), V. lasianthum Boiss. ex Bentham (Akdemir et al., 2004a, b), V. pterocalycinum var. mutense Hub.-Mor. (Tatli et al.,
2004), and V. salviifolium Boiss. (Akdemir et al., 2003, 2004c, 2005).

Reactive oxygen species (ROS) have been implicated in lipid peroxidation, inflammation, heart diseases, atherosclerosis, cataract, cognitive dysfunction, AIDS, cancer and aging. This has been of world-wide interest in endogenous and exogenous antioxidants. Plants have proven to be rich sources of radical scavengers. Therefore, it is important to look for effective radical scavengers by using various screening methods (Takamatsu et al., 2003a, b). Cell adhesion process also plays roles in pathological conditions such as chronic inflammation and cancer metastasis. Cell adhesion molecules (CAMs) are important in the regulation of the immune response and inflammation (Takamatsu et al., 2004).

In these contexts, natural compounds are receiving increasing attention. As a part of our ongoing research on Verbascum species growing in Turkey, 
we here report the possible biological activities of secondary metabolites from four Turkish Verbascum species.

\section{Material and Methods}

\section{Plant material}

Verbascum cilicicum Boiss. (Scrophulariaceae) was collected from Adana, between Pozantı and Ulukışla, Alihoca village, in July 2000. V. lasianthum Boiss. ex Bentham was collected in Urla, in August 1999. V. pterocalycinum var. mutense Hub.Mor. was collected from İçel, between Mut and Karaman, 930-1100 m, in July 2000. V. salviifolium Boiss. was collected from Burdur, Yesilova, Southwest of Burdur Lake, $880 \mathrm{~m}$, in June 2002 (Huber-Morath, 1978). Voucher specimens were deposited in the Herbarium of the Pharmacognosy Department, Faculty of Pharmacy, Hacettepe University, Ankara, Turkey (H. Duman and I. I. Tatli HUEF 00183, Z. S. Akdemir HUEF 99130, H. Duman and I. I. Tatli HUEF 00184, I. I. Tatli HUEF 02003, respectively).

\section{Extraction and isolation}

The extraction procedures of $V$. cilicicum, $V$. lasianthum, $V$. pterocalycinum var. mutense and $V$. salviifolium, the isolation and the structure elucidation of active compounds were given in detail in our previous papers (Akdemir et al., 2003, 2004a, b, c; Tatli et al., 2004).

\section{Pharmacological studies}

Reduction of DPPH radical by bioautographic assay

Methanolic solutions $(0.1 \%)$ of compounds 136 were chromatographed on a silica gel TLC plate using $\mathrm{CHCl}_{3} / \mathrm{CH}_{3} \mathrm{OH} / \mathrm{H}_{2} \mathrm{O}$ (61:32:7). After drying, TLC plates were sprayed with a $0.2 \%$ DPPH (1,1-diphenyl-2-picrylhydrazyl, Sigma) solution in $\mathrm{CH}_{3} \mathrm{OH}$. Compounds $\mathbf{1 - 1 5}$, showing a yellow-on-purple spot, were regarded as antioxidants (Takao et al., 1994).

Reduction of DPPH radical by spectrophotometric assay

The radical scavenging activity of the potent isolated compounds 1-15 was examined with the DPPH radical by a spectrophotometric method. ( \pm )- $\alpha$-Tocopherol (vitamin E, Sigma), ascorbic acid (vitamin C, Sigma) and 3-t-butyl-4-hydroxyanisole (3-BHA, Sigma) were used as control. $\mathrm{CH}_{3} \mathrm{OH}$ solutions of compounds $\mathbf{1}-\mathbf{1 5}$ at various concentrations $(10,25,50,100,200 \mu \mathrm{M})$ were added to $1.5 \times 10^{-5} \mathrm{M}$ DPPH in $\mathrm{CH}_{3} \mathrm{OH}$. The absorbance of the remaining DPPH was measured in 1-cm cuvettes with a Shimadzu UV-160A spectrophotometer at $520 \mathrm{~nm}$, after $30 \mathrm{~min}$ incubation at room temperature. Decreasing of the DPPH solution absorbance indicated an increase of the DPPH radical scavenging activity. This activity is given as \% DPPH radical scavenging that is calculated using the equation: [(control absorbance sample absorbance)/control absorbance] $\times 100$. A DPPH solution without sample solution was used as control (Hatano et al., 1989).

Microplate assay for the detection of oxidative products with DCFH-DA

This method is based on a fluorimetric assay described by Rosenkranz et al. (1992). Myelomonocyctic HL-60 cells $\left(1 \times 10^{6}\right.$ cells $/ \mathrm{ml}$, ATCC) were suspended in RPMI 1640 medium with 10\% FBS and antibiotics at $37{ }^{\circ} \mathrm{C}$ in $5 \% \mathrm{CO}_{2} / 95 \%$ air. $125 \mu \mathrm{l}$ of the cell suspension were added to a well of a 96-well plate. After treatment with a different concentration of the test materials for $30 \mathrm{~min}$, cells were stimulated with $100 \mathrm{ng} / \mathrm{ml}$ phorbol 12-myristate 13-acetate (PMA, Sigma) for $30 \mathrm{~min}$. Furthermore, cells were incubated for $15 \mathrm{~min}$ after the addition of $5 \mu \mathrm{g} / \mathrm{ml} 2^{\prime}, 7^{\prime}$-dichlorofluorescein diacetate (DCFH-DA, Molecular Probes). DCFH-DA is a non-fluorescent probe that diffuses into cells. Cytoplasmic esterases hydrolyze DCFH-DA to DCFH. Reactive oxygen species generated within HL-60 cells oxidize DCFH to the fluorescent dye $2^{\prime}, 7^{\prime}$-dichlorofluorescein (DCF). The ability of the test materials to inhibit exogenous cytoplasmic ROS-catalyzed oxidation of DCFH in HL-60 cells was measured by PMA-treated control incubations with and without the test materials. Levels of DCF were measured using a CytoFluor 2350 fluorescense measurement system (Millipore) with excitation at $485 \mathrm{~nm}$ (bandwidth $20 \mathrm{~nm}$ ) and emission at $530 \mathrm{~nm}$ (bandwidth $25 \mathrm{~nm}$ ) (Rosenkranz et al., 1992).

\section{Cell aggregation assay}

HL-60 cells were suspended at a density of $1 \times 10^{6}$ cells $/ \mathrm{ml}$. $150 \mu \mathrm{l}$ of the cell suspension were added to a well of a 96-well plate. After incubation with sample for $10 \mathrm{~min}$, PMA (10 ng/ml, final concentration) was added. The mixture was placed in a $\mathrm{CO}_{2}$ incubator and aggregation of the cells was observed $16 \mathrm{~h}$ after the PMA addition. The cell aggregation inhibitor cytochalasin $\mathrm{B}$, which is an 
exoenzyme from Clostridium botulinum, antiLFA-1 (lymphocyte-associated antigen-1), and anti-ICAM-1 (intercellular adhesion molecule-1) monoclonal antibodies (Santa Cruz Biotech, Inc., Santa Cruz, CA) were used as positive controls (Katagiri et al., 1999).

\section{XTT assay for cytotoxicity}

After sample exposure on cells for $18 \mathrm{~h}$, XTT assay was performed using the methods described by Scudiero et al. (1988). Briefly, $25 \mu \mathrm{l}$ of XTTPMS solution $(1 \mathrm{mg} / \mathrm{ml} \mathrm{XTT} \mathrm{solution} \mathrm{supplement}$ by $25 \mu \mathrm{M}$ of PMS) were added to HL-60 cells $\left(2 \times 10^{4}\right.$ cells in $225 \mu \mathrm{l}$ medium $)$ in each well on the microplates. After incubating for $4 \mathrm{~h}$ at $37^{\circ} \mathrm{C}$, absorbance at $450 \mathrm{~nm}$ was measured by a microplate reader (reference absorbance at $650 \mathrm{~nm}$ ) (Musza et al., 1994; Scudiero et al., 1988).

\section{Results and Discussion}

In a primary screening, 36 pure secondary metabolites from the Verbascum species examined and 15 compounds (1-15) showed antioxidant activities in TLC autographic assays with the DPPH radical. In the spectrophotometric assay, antioxi- dants 1-15 reacted with the stable free radical DPPH, resulting in the production of colourless 1,1-diphenyl-2-picrylhydrazyl, and showed a dosedependent reduction of DPPH, corresponding to the intensity of quenching of the DPPH radical (Hatano et al., 1989). The results are given in Table I.

So far many in vitro assay systems for the evaluation of antioxidants were reported, but it is important how to feedback the results of an in vitro assay into an evaluation in vivo. Fluorescent technology made it possible to evaluate antioxidants in live cells using specific probes such as DCFHDA. A cell-based method using a fluorescent technology is useful to directly examine the ability of natural products to penetrate cell membranes and inhibit ROS-catalyzed oxidation in living human cells (Bass et al., 1983). Therefore, the pure natural products 1-15 were also examined in the DCFHDA cellular-based assay. The inhibition effects of the compounds on ROS-catalyzed oxidation of DCFH in HL-60 cells are shown in Table II.

Among the compounds 1-15, verbascoside (4) showed a potent antioxidant effect $\left(\mathrm{IC}_{50} 4.0 \mu \mathrm{g} /\right.$ $\mathrm{ml})$. On the other hand, ilwensisaponin A $\left(2 ; \mathrm{IC}_{50}\right.$

Table I. Free radical scavenging effects of natural compounds $\mathbf{1 - 1 5}$ on DPPH radical.

\begin{tabular}{|c|c|c|c|c|c|c|}
\hline Compound & Source & $10 \mu \mathrm{M}^{\mathrm{a}}$ & $25 \mu \mathrm{M}$ & $50 \mu \mathrm{M}$ & $100 \mu \mathrm{M}$ & $200 \mu \mathrm{M}$ \\
\hline 6-O-Vaniloyl ajugol (1) & Verbascum lasianthum & $35.4^{\mathrm{b}}$ & 46.0 & 67.4 & 58.9 & 71.8 \\
\hline Ilwensisaponin A (2) & $\begin{array}{l}\text { Verbascum pterocalycinum } \\
\text { var. mutense }\end{array}$ & 39.8 & 64.8 & 29.9 & 77.7 & 77.5 \\
\hline Ilwensisaponin C (3) & $\begin{array}{l}\text { Verbascum pterocalycinum } \\
\text { var. mutense }\end{array}$ & 35.4 & 29.9 & 25.8 & 15.5 & 17.1 \\
\hline Verbascoside (4) & $\begin{array}{l}\text { Verbascum lasianthum } \\
\text { Verbascum pterocalycinum } \\
\text { var. mutense } \\
\text { Verbascum salviifolium }\end{array}$ & $\mathrm{IA}^{\mathrm{c}}$ & 23.1 & 41.0 & 89.9 & 73.9 \\
\hline$\beta$-Hydroxyacteoside (5) & Verbascum salviifolium & IA & 11.8 & 51.7 & 46.8 & 65.0 \\
\hline Martynoside (6) & Verbascum salviifolium & 10.8 & 9.2 & 45.8 & 71.1 & 76.2 \\
\hline Poliumoside (7) & Verbascum salviifolium & 13.9 & 32.8 & 46.3 & 68.8 & 73.7 \\
\hline Forsythoside B (8) & Verbascum salviifolium & IA & 13.2 & IA & 52.1 & 81.4 \\
\hline Angoroside A (9) & Verbascum salviifolium & IA & 27.7 & 28.7 & 46.2 & 38.8 \\
\hline $\begin{array}{l}\text { Dehydrodiconiferyl } \\
\text { alcohol-9- } O \text { - } \beta \text {-D-glucopyranoside (10) }\end{array}$ & Verbascum salviifolium & 3.9 & 7.7 & 18.2 & 19.9 & 62.9 \\
\hline $\begin{array}{l}\text { Dehydrodiconiferyl } \\
\text { alcohol-9'- } O \text { - } \beta \text {-D-glucopyranoside (11) }\end{array}$ & Verbascum salviifolium & 3.9 & 7.7 & 18.2 & 19.9 & 62.9 \\
\hline Apigenin $7-O$ - $\beta$-glucopyranoside (12) & Verbascum salviifolium & 78.4 & 80.4 & 85.3 & 95.0 & 91.7 \\
\hline Luteolin $7-O-\beta$-glucopyranoside (13) & Verbascum salviifolium & 94.4 & 88.6 & 69.4 & 89.3 & 75.0 \\
\hline Luteolin $3^{\prime}-O$ - $\beta$-glucopyranoside (14) & Verbascum salviifolium & 73.4 & 70.1 & 79.9 & 83.1 & 91.1 \\
\hline Chrysoeriol 7- $O-\beta$-glucopyranoside (15) & Verbascum salviifolium & 62.7 & 68.0 & 72.0 & 78.3 & 90.0 \\
\hline $3-\mathrm{BHA}^{\mathrm{d}}$ & & 67.3 & 51.8 & 56.8 & 69.3 & 83.6 \\
\hline Vitamin $C^{\mathrm{d}}$ & & 87.0 & 79.8 & 85.7 & 94.4 & IA \\
\hline Vitamin $\mathrm{E}^{\mathrm{d}}$ & & 81.0 & 89.9 & 81.9 & 93.7 & 98.3 \\
\hline
\end{tabular}

a Values are means of three independent determinations. ${ }^{\mathrm{b}} \%$ DPPH radical scavenging. ${ }^{\mathrm{c}}$ IA, inactive. ${ }^{\mathrm{d}}$ Used as a standard. 
Table II. Effects of natural products 1-15 on reactive oxygen species and HL-60 cell- aggregation and proliferation.

\begin{tabular}{|c|c|c|c|c|}
\hline Compound & $\begin{array}{l}\text { Antioxidant } \\
(D C F H) \\
\text { IC }_{50}[\mu \mathrm{g} / \mathrm{ml}]^{\mathrm{a}}\end{array}$ & $\begin{array}{c}\text { A. Cell- } \\
\text { aggregation } \\
\text { MIC }^{\mathrm{b}}[\mu \mathrm{g} / \mathrm{ml}]\end{array}$ & $\begin{array}{c}\text { B. Cell- } \\
\text { proliferation-XTT } \\
\text { IC }_{50}[\mu \mathrm{g} / \mathrm{ml}]^{\mathrm{a}}\end{array}$ & $\begin{array}{l}\text { Specific } \\
\text { index } \\
(\mathrm{B} / \mathrm{A})\end{array}$ \\
\hline 6- $O$-Vaniloyl ajugol (1) & $40.0 \pm 1.2$ & IA & IA & - \\
\hline Ilwensisaponin A (2) & $8.5 \pm 0.6$ & 6.9 & $4.0 \pm 0.7$ & 0.58 \\
\hline Ilwensisaponin C (3) & $45.0 \pm 1.3$ & 62.5 & $33.0 \pm 1.1$ & 0.53 \\
\hline Verbascoside (4) & $4.0 \pm 0.4$ & 62.5 & $>62.5$ & 1 \\
\hline$\beta$-Hydroxyacteoside (5) & $44.4 \pm 1.5$ & IA & IA & - \\
\hline Martynoside (6) & $30.0 \pm 2.2$ & IA & IA & - \\
\hline Poliumoside (7) & $20.0 \pm 1.0$ & IA & IA & - \\
\hline Forsythoside B (8) & $16.4 \pm 0.9$ & IA & IA & - \\
\hline Angoroside A (9) & $17.3 \pm 0.7$ & IA & IA & - \\
\hline $\begin{array}{l}\text { Dehydrodiconiferyl } \\
\text { alcohol-9- } O \text { - } \beta \text {-D-glucopyranoside (10) }\end{array}$ & $\mathrm{IA}^{\mathrm{c}}$ & IA & IA & - \\
\hline $\begin{array}{l}\text { Dehydrodiconiferyl } \\
\text { alcohol-9'- } O-\beta \text {-D-glucopyranoside (11) }\end{array}$ & IA & IA & IA & - \\
\hline Apigenin $7-O$ - $\beta$-glucopyranoside (12) & $41.8 \pm 1.7$ & IA & IA & - \\
\hline Luteolin 7-O- $\beta$-glucopyranoside (13) & $17.0 \pm 1.1$ & IA & IA & - \\
\hline Luteolin 3'-O- $\beta$-glucopyranoside (14) & $22.0 \pm 0.7$ & IA & IA & - \\
\hline Chrysoeriol 7- $O-\beta$-glucopyranoside (15) & $34.2 \pm 1.3$ & IA & IA & - \\
\hline Vitamin $\mathrm{C}^{\mathrm{d}}$ & $4.4 \pm 0.8$ & & & \\
\hline Cytochalasin $\mathrm{B}^{\mathrm{d}}$ & & 2.3 & $43.0 \pm 2.2$ & 18.7 \\
\hline
\end{tabular}

a Values are means of three independent determinations \pm SE. ${ }^{b}$ MIC, minimum inhibitory concentration. ${ }^{c}$ IA, inactive. ${ }^{\mathrm{d}}$ Used as a standard.

$8.5 \mu \mathrm{g} / \mathrm{ml})$ showed a moderate antioxidant activity, while the other compounds displayed weak activity, except for compounds $\mathbf{1 0}$ and $\mathbf{1 1}$ which were inactive.

In order to determine the effects of isolated compounds on immunological and inflammatory reactions, they were also evaluated for their in vitro effects on LFA-1/ICAM-1-mediated cell aggregation using the HL-60 cell line. In a primary screening the cell aggregation and XTT method were reasonable assays for the selection of cell adhesion inhibitors (Takamatsu et al., 2004). Therefore, the isolated compounds $\mathbf{1}-\mathbf{1 5}$ were evaluated as having inhibitory activity for LFA-1/ICAM1-mediated cell aggregation of HL-60 cells (Table II). Ilwensisaponin A (2) inhibited the cell aggregation (MIC $6.9 \mu \mathrm{g} / \mathrm{ml}$ ) as compared to cytochalasin B (MIC $2.3 \mu \mathrm{g} / \mathrm{ml}$ ). Ilwensisaponin C (3; MIC $62.5 \mu \mathrm{g} / \mathrm{ml}$ ) and verbascoside (4; MIC $62.5 \mu \mathrm{g} / \mathrm{ml})$ were weakly active in the primary cell aggregation assay, while ilwensisaponin A (2) was $>10$-fold more cytotoxic ( $\left.\mathrm{IC}_{50} 4.0 \mu \mathrm{g} / \mathrm{ml}\right)$ than cytochalasin $\mathrm{B}\left(\mathrm{IC}_{50} 43.0 \mu \mathrm{g} / \mathrm{ml}\right)$ as determined by the XTT assay. Furthermore, none of the other compounds were active in the cell aggregation assay.

\section{Conclusion}

Several phenolic and terpenic compounds have been reported to be good antioxidants in some in vitro antioxidative assay models (Chander et al., 1992; Harborne, 1994; Hostettmann and Marston, 1995; Jimenez and Riguera, 1994; Zhao et al., 2005). However, there is no report concerning the ROS-catalyzed oxidation of isolated compounds in living human cells.

According to the structure-activity relationship, martynoside (6), forsythoside B (8), angoroside A (9) and poliumoside (7) showed weak activity as compared to verbascoside (4). Thus, antioxidative activity might be mainly related to the number of aromatic hydroxy groups, the structure of the acyl moiety and the number of sugar moieties. However, modification of the sugar chain or replacement of hydroxy groups by methoxy groups in the structure might of minor importance under this experiment condition. Besides He et al. (2000) found that poliumoside (7) had shown significant inhibitory effects on free radical-induced hemolysis of red blood cells and free radical scavenging activities in vitro due to the presence of the rhamnosyl at C-6". However, poliumoside (7) has a weak activity to penetrate cell membranes and inhibit ROS-catalyzed oxidation in living human cells in the present study (He et al., 2000). 
The antioxidant activities of flavonoids decreased in the following order: luteolin 7-O- $\beta$-glucopyranoside $(\mathbf{1 3})>$ luteolin $3^{\prime}-O-\beta$-glucopyranoside (14) $>$ chrysoeriol $7-O-\beta$-glucopyranoside (15) $>$ apigenin $7-O-\beta$-glucopyranoside (12). The $\mathrm{C} 2-\mathrm{C} 3$ double bond of the $\mathrm{C}$ ring appears to increase the scavenger activity because it confers stability to the phenoxy radicals produced, while the 4-oxo group increases the free radical scavenger activity by delocalizing electrons from the B ring. The presence of both 7- and 5- and additionally 3-hydroxy groups in rings $\mathrm{A}$ and $\mathrm{C}$ is required for maximum radical scavenging potential. Besides, some of the activities such as antitumour and cytotoxic effects of phenolic compounds are mainly dependent on the ortho-dihydroxy aromatic systems in their structures. Methylations of at least one of the ortho-dihydroxy groups abolishes the activity (Takamatsu et al., 2003a). In the present study, the finding is that luteolin $7-O-\beta$ glucopyranoside (13) with ortho-dihydroxy groups elicited stronger activity than chrysoeriol $7-O-\beta$ glucopyranoside (15) and apigenin 7-O- $\beta$-glucopyranoside (12). Moreover, in the same manner, it was also found to be more active than luteolin $3^{\prime}$ $O$ - $\beta$-glucopyranoside (14) due to the presence of a glucopyranosyl unit at C-3' position.

Additionally, it was displayed that vaniloyl ajugol showed moderate activity, because of its phenolic system, although few reports appeared in the literature on the antioxidant activity of iridoid glycosides (Chander et al., 1992).

The antioxidant activity of triterpenic saponins was found to be mainly dependent on their olefinic structures and the number of sugars, depending on the type, their linkage to each other, and location within the molecule. In addition monodesmosidic saponins in which the sugar units are attached to the aglycone at the C-3 position are more potent in this antioxidant system. On the other hand, methylation of at least one of the hydroxy groups may abolish the activity as evidenced by the observation that methoxylated derivatives like ilwensisaponin $\mathrm{C}$ may lost their activity (Hostettmann and Marston, 1995).

Potent antioxidants were identified by using the solution-based chemical assay along with the cellular-based assay, and we were able to compare the results in both systems (Tables I, II). Most of the compounds, except for compounds $\mathbf{1 0}$ and 11, not only act as antioxidants in solution-based antioxidant assays but can also be taken up by living cells maintaining their activity. Compounds $\mathbf{1 0}$ and $\mathbf{1 1}$ were shown to be active in the solution-based chemical assay, but had no significant activity inside cells. This suggests that these compounds do not enter the cells due to poor cellular uptake or reduced medium solubility, or perhaps lack the capacity to quench DCF fluorescence inside the cell (Takamatsu et al., 2003b).

ROS including hydroperoxide and lipid peroxides are thought not only to injure cells but also to induce the expression of intercellular adhesion molecule-1. Therefore, the antioxidant effects produced by compounds $1-9,12-15$ could partially contribute to the cell aggregation inhibitory effect. As results of our screening programme, ilwensisaponin A (2), ilwensisaponin C (3) and verbascoside (4) inhibited cell aggregation, while none of the other compounds were specific inhibitors of LFA-1/ICAM-1-mediated cell aggregation. But the results were reproducible and the dose-response behaviour is characteristic for the cell aggregation assay (Takamatsu et al., 2004).

In conclusion, the structure-activity relationship studies of oleanan-type triterpenoid saponins suggests that the magnitude of the cell aggregation activity has often been linked with anti-inflammatory and immunostimulant activities of the saponins. The availability of a longer sugar chain and the number of hydroxy groups lead to an increase of activity. Monodesmosidic saponins are more active than the bidesmosides in killing cancer cells (Hostettmann and Marston, 1995). On the other hand, phenylethanoid glycosides, especially verbascoside (4), are considered to show a biphasic effect on cancer cells, that is cytotoxic activity. Furthermore, this effect depends on the type of cells. In the case of HeLa cells, the cytotoxic activity at low concentration could not be so strong (Inoue et al., 1998).

Finally, it is intriguing to note that the cytotoxic and antioxidant activity of Turkish Verbascum species is contributed to, mainly, saponins $\mathbf{2}, \mathbf{3}$ and the phenylethanoid glycoside 4 . In order to correlate the obtained data with other effects in the field of cytotoxicity and radical scavenging activity of effective compounds, further examinations in different cellular and enzymatic assays should be evaluated. Examination of Verbascum species with regard to their biological activity and chemical contents support the traditional use of Verbascum species and may give a new insight into the usage of Verbascum in Turkey. 


\section{Acknowledgements}

The authors thank Prof. Dr. Hayri Duman, Gazi University, Faculty of Science, Department of Bot- any, Etiler, Ankara, Turkey, for the authentification of the plant specimen. This work was partially financial supported by the Research Fund of Hacettepe University (Project No. 0001301003 ).
Akdemir Z. S., Tatli I. I., Bedir E., and Khan I. A. (2003), Antioxidant flavonoids from Verbascum salviifolium Boiss. J. Pharm. Sci. (FABAD) 28, 71-75.

Akdemir Z. S., Tatli I. I., Bedir E., and Khan I. A. (2004a), Acylated iridoid glycosides from Verbascum lasianthum. Turk. J. Chem. 28, 101-110.

Akdemir Z. S., Tatli I. I., Bedir E., and Khan I. A. (2004b), Iridoid and phenylethanoid glycosides from Verbascum lasianthum. Turk. J. Chem. 28, 227-234.

Akdemir Z. S., Tatli I. I., Bedir E., and Khan I. A. (2004c), Neolignan and phenylethanoid glycosides from Verbascum salviifolium Boiss. Turk. J. Chem. 28, $1-8$.

Akdemir Z. S., Tatli I. I., Bedir E., and Khan I. A. (2005), Two new iridoid glycosides from Verbascum salviifolium Boiss. Z. Naturforsch. 60b, 113-117.

Bass D. A., Parce J. W., Dechatelet L. R., Szejda P., Seeds M. C., and Thomas M. (1983), Flow cytometric studies of oxidative product formation by neutrophils: a graded response to membrane stimulation. J. Immunol. 130, 1910-1917.

Baytop T. (1999), Therapy with Medicinal Plants in Turkey (Past and Present), $2^{\text {nd }}$ ed. Nobel Tip Kitabevleri Ltd., Istanbul, pp. 334-335.

Chander R., Kapoor N. K., and Dhawan B. N. (1992), Picroliv, piroside-I and kutkoside from Picrorhiza kurrooa are scavengers of superoxide anions. Biochem. Pharmacol. 44, 180-183.

Harborne J. B. (1994), The Flavonoids, Advances in Research since 1986. Chapman \& Hall, New York.

Hatano T., Edamatsu R., Hiramatsu M., Mori A., Fujita Y., and Yasuhara T. (1989), Effects of the interaction of tannins with co-existing substances. 6. Effects of tannins and related polyphenols on superoxide anion radical and on 1,1-diphenyl-2-picrylhydrazyl radical. Chem. Pharm. Bull. 37, 2016-2021.

He Z. D., Lau K. M., Xu H. X., Li P. C., and But P. P. H. (2000), Antioxidant activity of phenylethanoid glycosides from Brandisia hancei. J. Ethnopharmacol. 71, $483-486$.

Hostettmann K. and Marston A. (1995), Saponins. Cambridge University Press, Cambridge, UK.

Huber-Morath A. (1978), Flora of Turkey and the East Aegean Islands. In: Verbascum (Davis P. H., ed.). University Press, Edinburgh, pp. 461-603.

Inoue M., Sakuma Z., Ogihara Y., and Saracoglu I. (1998), Induction of apoptotic cell death in HL-60 cells by acteoside, a phenylethanoid glycoside. Biol. Pharm. Bull. 21, 81-83.

Jimenez C. and Riguera R. (1994), Phenylethanoid glycosides in plants: Structure and biological activity. Nat. Prod. Rep. 11, 591-606.
Katagiri K., Yokosawa H., Kinashi T., Kawashima S., Irie S., Tanaka K., and Katagiri T. (1999), Ubiquitin-proteasome system is involved in induction of LFA-1/ ICAM-1 dependent adhesion of HL-60 cells. J. Leukocyte Biol. 65, 778-785.

Musza L. L., Killar L. M., Speight P., McElhiney S., Barrow C. J., Gillium A. M., and Cooper R. (1994), Potent new cell adhesion inhibitory compounds from the root of Trichilia rubra. Tetrahedron 50, 1369-1378.

Rosenkranz A. R., Schmaldienst S., Stuhlmeier K. M., Chen W., Knapp W., and Zlabinger G. J. (1992), A microplate assay for the detection of oxidative products using $2^{\prime}, 7^{\prime}$-dichlorofluorescein-diacetate. J. Immunol. Methods 156, 39-45.

Scudiero D. A., Shoemaker R. H., Paull K. D., Monks A., Tierney S., Nofziger T. H., Currens M. J., Seniff D., and Boyd M. R. (1988), Evaluation of a soluble tetrazolium/formazan assay for cell growth and drug sensitivity in culture using human and other tumor cell lines. Cancer Res. 48, 4827-4833.

Takamatsu S., Galal A. M., Ross S. A., Ferreira D., ElSohly M. A., Ibrahim A. R. S., and El-Feraly F. S. (2003a), Antioxidant effect of flavonoids on DCF production in HL-60 cells. Phytother. Res. 17, 963966.

Takamatsu S., Hodges T. W., Rajbhandari I., Gerwick W. H., Hamann M. T., and Nagle D. G. (2003b), Marine natural products as novel antioxidant prototypes. J. Nat. Prod. 66, 605-608.

Takamatsu S., Nagle D. G., and Gerwick W. H. (2004), Secondary metabolites from marine cyanobacteria and algae inhibit LFA-1/ICAM-1 mediated cell adhesion. Planta Med. 70, 127-131.

Takao T., Kitatani F., Watanabe N., Yagi A., and Sakata K. (1994), A simple screening method for antioxidants and isolation of several antioxidants produced by marine bacteria from fish and selfish. Biosci. Biotech. Biochem. 58, 1780-1783.

Tatli I. I., Akdemir Z. S., Bedir E., and Khan I. A. (2003), 6- $O$ - $\alpha$-L-Rhamnopyranosylcatalpol derivative iridoids from Verbascum cilicicum. Turk. J. Chem. 27, $765-772$.

Tatli I. I., Akdemir Z.S., Bedir E., and Khan I. A. (2004), Saponin, iridoid, phenylethanoid and monoterpene glycosides from Verbascum pterocalycinum var. mutense. Turk. J. Chem. 28, 111-122.

Turker U. A. and Camper N. D. (2002), Biological activity of common mullein, a medicinal plant. J. Ethnopharmacol. 82, 117-125.

Zhao C., Dodin G., Yuan C., Chen H., Zheng R., Jia Z., and Fan B. T. (2005), "In vitro" protection of DNA from Fenton reaction by plant polyphenol verbascoside. Biochim. Biophys. Acta 1723, 114-123. 